
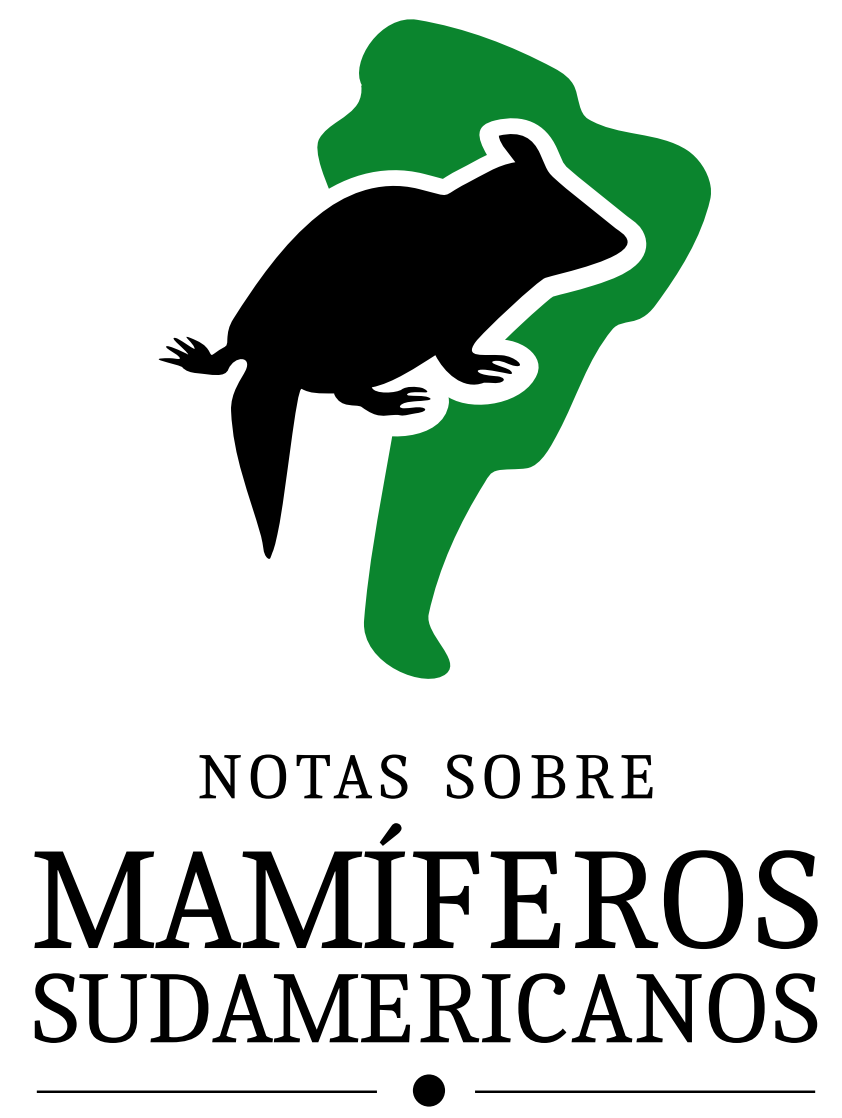

NOTAS SOBRE

MAMÍFEROS

$\underline{\text { SUDAMERICANOS }}$ 


\title{
In search of hepatitis $E$ virus infection in wild boar and cattle from Argentina
}

\author{
Luciano F. La Sala (1), Soledad Barandiaran (2), María E. Eirin (3), Ximena Ferrara \\ Muñiz (3), Sergio Abate (4), Silvia Sánchez Puch (5), Verónica Mathet (5), \\ and Cecilia M. Delfino (5)
}

\begin{abstract}
(1) Instituto de Ciencias Biológicas y Biomédicas del Sur (INBIOSUR), Universidad Nacional del Sur (UNS) - Consejo Nacional de Investigaciones Científicas y Técnicas (CONICET), Bahía Blanca, Buenos Aires, Argentina. (2) Instituto de Investigaciones en Producción Animal (INPA), Consejo Nacional de Investigaciones Científicas y Técnicas (CONICET), Universidad de Buenos Aires (UBA), Ciudad Autónoma de Buenos Aires, Argentina. (3) Instituto Nacional de Tecnología Agropecuaria (INTA), Instituto de Agrobiotecnología y Biología Molecular (IABIMO), INTA - Consejo Nacional de Investigaciones Científicas y Técnicas (CONICET), Hurlingham, Buenos Aires, Argentina. (4) Universidad Nacional de Río Negro-Sede Atlántica, Centro de Investigaciones y Transferencia de Río Negro (UNRN-CONICET), Viedma, Río Negro, Argentina. (5) Instituto de Investigaciones en Microbiología y Parasitología Médica (IMPAM), UBA - CONICET, Ciudad Autónoma de Buenos Aires, Argentina. [correspondence: lic.ceciliadelfino@gmail.com]
\end{abstract}

Citación: La SALA, L. F., ET AL. 2022. In search of hepatitis $\mathrm{E}$ virus infection in wild boar and cattle from Argentina. Notas sobre Mamíferos Sudamericanos 4:e22.1.2

\begin{abstract}
Hepatitis E virus (HEV) is a pathogen with zoonotic potential that affects domestic pigs, wild boar Sus scrofa, and humans, among other species. The HEV has been reported in wild boar from Argentina and Uruguay, but knowledge about the epidemiology of this virus is still very scarce in this region. The objective of this study was to evaluate the circulation of HEV in wild boar and cattle from Argentina through serological (ELISA) and molecular (PCR) analyses. All samples were negative. However, we stress the importance of reporting negative cases since these represent key inputs in future research and risk analysis, mainly in association with the potential for virus transmission between wild boar and susceptible native species.
\end{abstract}

Key words: epidemiological surveillance, hepatitis E virus, Sus scrofa.

RESUMEN. En busca del virus de la hepatitis E en jabalíes y vacunos de Argentina

El virus de hepatitis $\mathrm{E}$ (VHE) es un patógeno con potencial zoonótico que afecta al cerdo doméstico, al jabalí Sus scrofa y al ser humano, entre otras especies. El VHE ha sido reportado en jabalíes de Argentina y Uruguay, pero el conocimiento acerca de la epidemiología de este virus es aún muy escaso en la región. El objetivo del presente estudio fue evaluar la circulación del VHE es poblaciones de jabalí y ganado vacuno en Argentina, a través de análisis serológicos (ELISA) y moleculares (PCR). No se hallaron muestras positivas. Sin embargo, se resalta la importancia de reportar casos negativos como insumo clave de futuras investigaciones y análisis de riesgo, sobre todo en relación a una posible transmisión del virus entre jabalíes y especies nativas susceptibles.

Palabras clave: Sus scrofa, vigilancia epidemiológica, virus de hepatitits E. 
Hepatitis E virus (HEV) is a hepatotropic infectious agent that generally causes self-limiting acute hepatitis in healthy individuals and chronic hepatitis in immunocompromised human patients. HEV genotypes 3 and 4 are zoonotic (Hoofnagle et al. 2012), and it has been estimated to cause a global disease burden of 3.4 million acute cases, 70,000 deaths, and 3,000 stillbirths per year (Rein et al. 2012). In South America, HEV is widely distributed in the domestic pig population, with prevalence ranging between 8.6\% and 24.3\% in Brazil (Vitral et al. 2005; De Souza et al. 2012), $100 \%$ in Colombia (Forero et al. 2015), 5.3\% in Chile (Reinhardt et al. 2003), 46.8\% in Uruguay (Mirazo et al. 2018), and 4-58\% in Argentina (Munné et al. 2006).

Antibodies against HEV have been reported in several deer, non-human primates and other species (Spahr et al. 2018). Also, cattle have been suggested as HEV reservoir (Wei et al. 2020). Interestingly, similar HEV strains were detected in wild boar Sus scrofa Linnaeus, 1758, roe deer Capreolus capreolus Linnaeus, 1758, and red deer Cervus elaphus Linnaeus, 1758, from the same hunting area in Germany (AnheyerBehmenburg et al. 2017), where the authors suggested a primary HEV circulation in wild boar with accidental or spillover transmission to deer. Other research, however, supports the hypothesis of deer as a true reservoir (Van der Poel 2014).

In South America, HEV antibodies and HEV RNA have been detected in wild boar from Uruguay and Argentina (Mirazo et al. 2018; Pisano et al. 2019), suggesting the potential role of this invasive species as reservoir and spreader of the virus. HEV has been found in the muscle, blood, and liver of infected animals (Schielke et al. 2015; Anheyer-Behmenburg et al. 2017), with the latter organ being the main site of HEV replication in pigs (Halbur et al. 2001) and other species (Purcell et al. 2011).

Despite the evidence mentioned above, research about HEV circulation in wild boar or other susceptible species in South America remains scarce, and viral circulation has not been explored in artiodactyls in general, let alone in native ones. Moreover, detection methods for HEV remain challenging because an efficient cell culture system has yet to be developed (Harrison \& DiCaprio 2018), which poses an obstacle to studying HEV epidemiology at the interface between wildlife, domestic animals, and humans.

A serological and molecular survey was conducted in wild boar and domestic cattle (Bos primigeniustaurus [Linnaeus, 1758]) populations from Argentina. An opportunistic sampling scheme was used to collect 106 serum samples from hunted wild boar in the provinces of Río Negro ( $n=25)$, Buenos Aires ( $n=14)$, Entre Ríos ( $n=29)$ and Corrientes $(n=38)$, and cattle in the province of Santa Fe $(n=64)$. The centroids of the sampled departments in each province are presented in Figure 1. Wild boar blood was collected post-mortem by cava vein puncture, whereas cattle were sampled alive via jugular puncture. Samples were centrifuged and the obtained serum was frozen $\left(-70^{\circ} \mathrm{C}\right)$ until analyzed. The presence of IgG anti-HEV antibodies was tested by ELISA (IgG anti- HEV, Diapro SRL, Italia) and HEV RNA by RT-nested-PCR ORF2 following Huang et al. (2002). The PCR was performed including negative controls following Kwok \& Higuchi (1989), and positive controls donated by Prof. Paul K. S. Chan (University of Hong Kong).

Uncertainty in HEV prevalence was modeled under the hypothesis that HEV is present in the wild boar (Pisano et al. 2018) and cattle populations. Then, a Beta distribution 
with a Uniform $[0,1]$ prior was included in Monte Carlo simulations (10,000 iterations) for wild boar and cattle. All the analyses were done using the programming language $\mathrm{R}$ (R Core Team 2019).

All the assayed samples were negative by both methods (ELISA and PCR). Simulation results yielded a mean prevalence of $0.94 \%(\mathrm{SD}=0.93 ; 95 \% \mathrm{CI}=0.02-3.47)$ in wild boar, and $1.5 \%(\mathrm{SD}=1.5 ; 95 \% \mathrm{CI}=0.04-5.45)$ in cattle.

Previous research conducted in wild boar population from the same region in Río Negro province in Argentina (Pisano et al. 2019) reported a 19.6\% (20/102) of positive samples through serology. Although the authors were able to amplify ORF2 HEV-RNA in two samples, they could not confirm the identity of the amplified PCR product as belonging to HEV by sequencing.

Here, we rule out methodological issues causing our negative results since our analyses were done adhering closely to the same protocols used by a related investigation that reported positive results in wild boar (Pisano et al. 2018). Instead, our negative results could be explained by randomness, low population prevalence in the study area, small sample size, or any combination of these factors. Further samplings across a broader geographical area are necessary to confirm HEV circulation in areas of Argentina other than Río Negro province.

The wild boar is an invasive and rapidly expanding species in Argentina and neighboring countries (Ballari et al. 2019), and the interaction between wild boar, native wildlife, and domestic animals implies an increased risk of pathogen transmission, including HEV, among populations (Barrios-Garcia \& Ballari 2012; La Sala et al. 2021). Also, wild boar hunting has become a common practice as a means of subsistence in rural populations in Argentina, thus leading to enhanced risk for HEV transmission to humans (Kozyra et al. 2020). The effects of wild boar on native wildlife are beginning to be addressed in South America, but their potential impact as pathogen spreaders to native wildlife has remained largely unexplored. Considering the potential role of wild boar as spreader of pathogens like HEV, it is desirable that institutions responsible for animal health and pest management ramp up viral surveillance in their populations, especially in areas where wild boar cohabit with threatened native species of particular concern.

This is the first study assessing HEV infection in bovines from Argentina. Although we found no evidence of past or active HEV infection in any of the species studied, further works will be essential to elucidate the role of bovines and wild boar as HEV reservoirs and disease spreaders to humans and susceptible wildlife. Finally, we highlight the contribution of manuscripts reporting negative data, which are greatly underrepresented in the literature despite their relevance to understanding the ecology of wildlife diseases (Stallknecht 2007), identifying reservoir host populations for pathogens, and performing robust quantitative risk analysis (Jakob-Hoff et al. 2014). 


\section{ACKNOWLEDGMENTS}

The authors thank Julia Sabio y Garcia for the English revision of the manuscript. This work was supported by the Agencia Nacional de Promoción Científica y Tecnológica (PICT 2016-0698 and PICT 2018-03526).

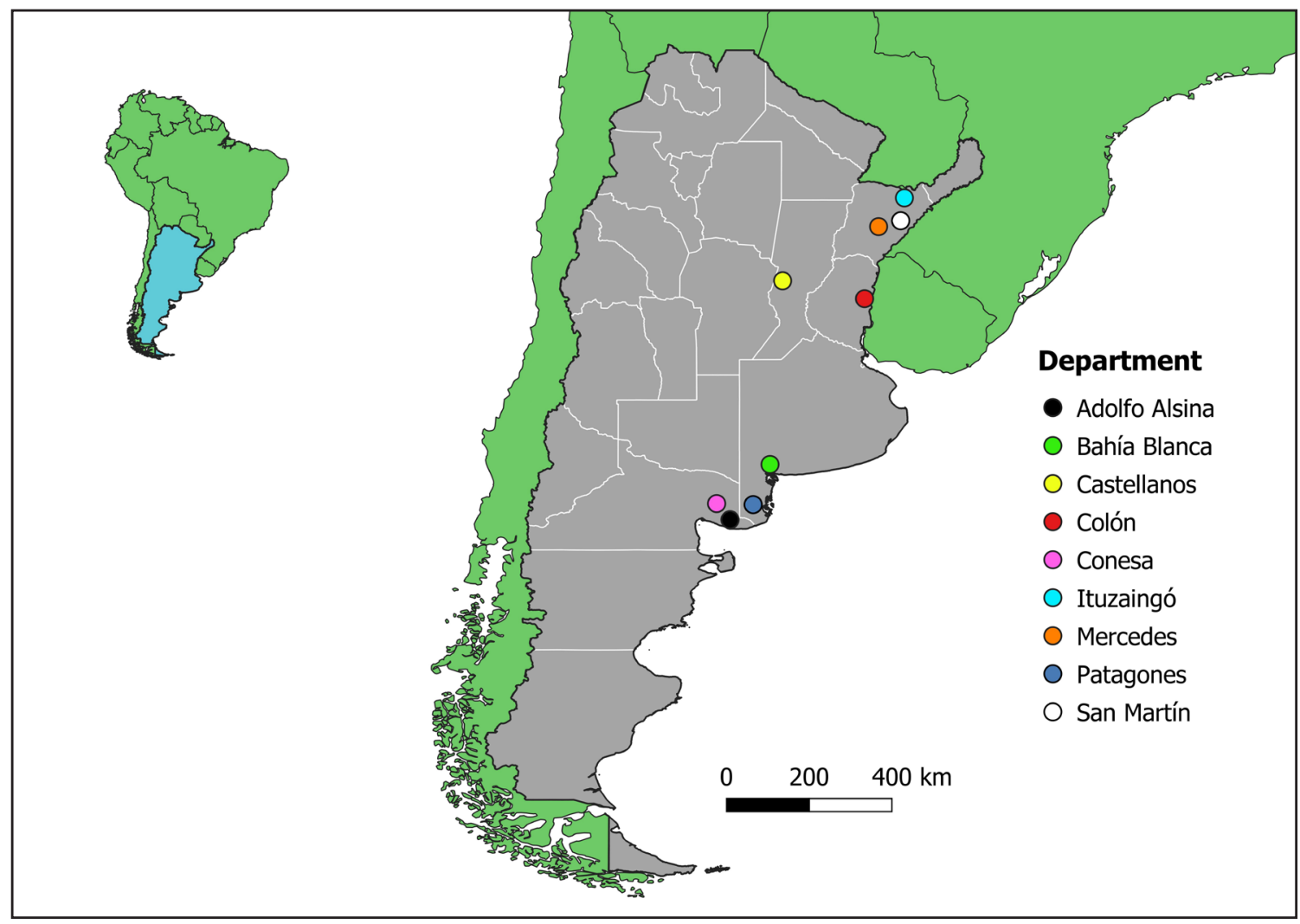

Figure 1. Distribution of sampling sites for HEV in wild boar and cattle in Argentina. Wild boar were sampled in all but Castellanos department, where only cattle were sampled. The map inset (upper left corner) represents Argentina's location in South America. 


\section{LITERATURE CITED}

Anheyer-Behmenburg, H. E., K. Szabo, U. Schotte, A. Binder, G. Klein \& R. Johne. 2017. Hepatitis E virus in wild boars and spillover infection in red and roe deer, Germany, 2013-2015. Emerging Infectious Diseases 23:130-133.

Ballari, S. A., et al. 2019. Sus scrofa Categorización 2019 de los mamíferos de Argentina según su riesgo de extinción. Lista Roja de los mamíferos de Argentina (SAyDS-SAREM, eds.). <http://cma. sarem.org.ar>.

Barrios-Garcia, M. N., \& S. A. Ballart. 2012. Impact of wild boar (Sus scrofa) in its introduced and native range: a review. Biological Invasions 14:2283-2300.

De SouZA, A. J., ET AL. 2012. HEV infection in swine from Eastern Brazilian Amazon: evidence of coinfection by different subtypes. Comparative Immunology, Microbiology $\&$ Infectious Diseases 35:477-485.

Forero, J., ET AL. 2015. Serological evidence of hepatitis E virus infection in Antioquia, Colombia slaughtered pigs. Revista MVZ Córdoba 20:4602-4613.

HaLBUR, P. G., ET AL. 2001. Comparative pathogenesis of infection of pigs with hepatitis E viruses recovered from a pig and a human. Journal of Clinical Microbiology 39:918-923.

HaRRISON, L. H., \& E. DiCAPRIO. 2018. Hepatitis E virus: an emerging foodborne pathogen. Frontiers in Sustainable Food Systems 2:14.

Hoofnagle, J. H., K. E. Nelson, \& R. H. Purcell. 2012. Hepatitis E. New England Journal of Medicine $367: 1237-244$.

HuANG, F. F., ET AL. 2002. Detection by reverse transcription-PCR and genetic characterization of field isolates of swine hepatitis E virus from pigs in different geographic regions of the United States. Journal of Clinical Microbiology 40:1326-332.

Jakob-Hoff, R. M., S. C. MacDiarmid, C. Lees, P. S. Miller, D. Travis, \& R. Kock. 2014. Manual of procedures for wildlife disease risk analysis. World Organisation for Animal Health, Paris. Published in association with the International Union for Conservation of Nature and the Species Survival Commission.

Kozyra, I., A. Jabłonśski, E. Bigoraj, \& A RzeżuTKa. 2020. Wild Boar as a sylvatic reservoir of hepatitis E virus in Poland: a cross-sectional population study. Viruses 12:1113.

Kwoк, S., \& R. Higuchi. 1989. Avoiding false positives with PCR. Nature 339:237-238.

La Sala, L. F., J. M. Burgos, A. L. Scorolli, K. VanderWaal, \& S. M. Zalba. 2021. Trojan hosts: the menace of invasive vertebrates as vectors of pathogens in the Southern Cone of South America. Biologial Invasions 23:2063-2076.

Mirazo, S., ET AL. 2018. Serological and virological survey of hepatitis E virus (HEV) in animal reservoirs from Uruguay reveals elevated prevalences and a very close phylogenetic relationship between swine and human strains. Veterinary Microbiology 213:21-27.

MunNÉ, M. S., ET AL. 2006. Identification of the first strain of swine hepatitis E virus in South America and prevalence of anti-HEV antibodies in swine in Argentina. Journal of Medical Virology 78:1579-1583.

Pisano, M. B., M. G. Martinez-Wassaf, S. Mirazo, A. Fantilli, J. Arbiza, J. D. Debes, \& V. E. Ré. 2018. Hepatitis E virus in South America: The current scenario. Liver International 38:1536-1546.

Pisano, M. B., M. Winter, N. Raimondo, M. G. Martínez-Wassaf, S. D. Abate, \& V. E. Ré. 2019. New pieces in the transmission cycle of the hepatitis E virus in South America: first viral detection in wild boars from Argentina. Transactions of the Royal Society of Tropical Medicine and Hygiene 113:497-499.

Purcell, R. H. et Al. 2011. Hepatitis E virus in rats, Los Angeles, California, USA. Emerging Infectious Diseases 17:2216-2222.

R CoRE TeAm. 2019. R: A language and environment for statistical computing. R Foundation for Statistical Computing, Vienna, Austria. < https://www.R-project.org/>.

Rein, D. B., G. A. Stevens, J. Theaker, J. S. Wittenborn, \& S. T. Wiersma. 2012. The global burden of hepatitis E virus genotypes 1 and 2 in 2005. Hepatology 55:988-997.

Reinhardt, G., H. Ibarra, S. Riedemann, \& I. Vega. 2003. Swine hepatitis E preliminary serological study in Chile. Archivos de Medicina Veterinaria 35:233-236. 
SchIELKE, A., ET AL. 2015. Hepatitis E virus antibody prevalence in hunters from a district in Central Germany, 2013: A cross-sectional study providing evidence for the benefit of protective gloves during disembowelling of wild boars. BMC Infectious Diseases 15:1-8.

Spahr, C., T. Knauf-Witzens, T. Vahlenkamp, R. G. Ulrich, \& R. Johne. 2018. Hepatitis E virus and related viruses in wild, domestic and zoo animals: A review. Zoonoses Public Health 65:11-29.

Stallknecht, D. E. 2007. Impediments to wildlife disease surveillance, research, and diagnostics. Current Topics in Microbiology and Immunology 315:445-461.

VAN DER PoEL, W. H. 2014. Food and environmental routes of hepatitis E virus transmission. Current Opinion in Virology 4:91-96.

Vitral, C. L., M. A. Pinto, L. L. Lewis-Ximenez, Y. E. Khudyakov, D. R. dos Santos, \& A. M. Gaspar. 2005. Serological evidence of hepatitis $\mathrm{E}$ virus infection in different animal species from the Southeast of Brazil. Memórias do Instituto Oswaldo Cruz 100:117-122.

Wei, D., Y. Zhao, Y. Jia, X. Hao, J. Situ, W. Yu, Huang F., \& H. Jiang. 2020. Hepatitis E virus infection in buffaloes in South China. Arquivo brasileiro de medicina veterinária e zootecnia 72:1122-1126. 